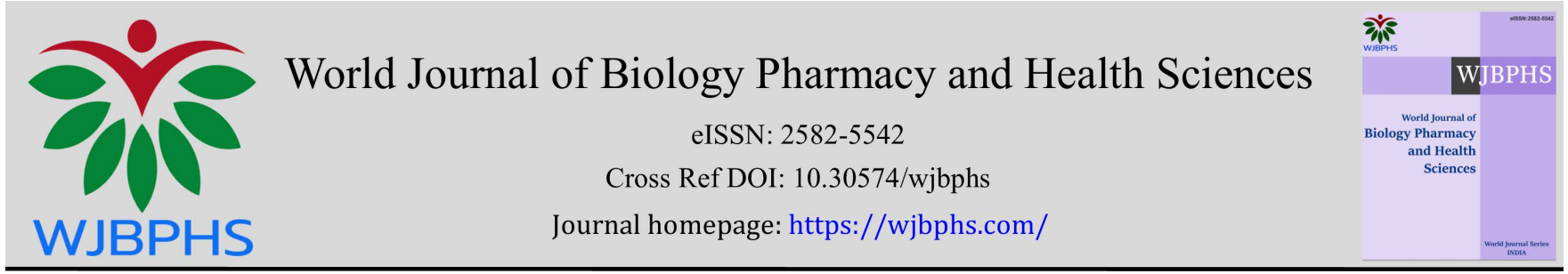

(RESEARCH ARTICLE)

\title{
Alleviation of collagen-induced arthritis through cytokine-modulatory activity of Brazilian propolis AF-08 in mice
}

\author{
Kurokawa Masahiko ${ }^{1, *}$, Akashi Toshi ${ }^{2}$, Yoshida Hiroki ${ }^{1}$, Sugita Chihiro ${ }^{1}$ and Tsutsumi Shigetoshi ${ }^{3}$ \\ ${ }^{1}$ Department of Biochemistry, Graduate School of Clinical Pharmacy, Kyushu University of Health and Welfare, Nobeoka, \\ Miyazaki 882-8508, Japan. \\ 2 Department of Microbiology and Infectious Diseases, School of Pharmaceutical Sciences, Kyushu University of Health and \\ Welfare, Nobeoka, Miyazaki 882-8508, Japan. \\ ${ }^{3}$ Amazonfood Ltd., Misaki, Chiyoda-ku, Tokyo, Japan.
}

World Journal of Biology Pharmacy and Health Sciences, 2021, 06(01), 001-009

Publication history: Received on 24 February 2021; revised on 27 March 2021; accepted on 30 March 2021

Article DOI: https://doi.org/10.30574/wjbphs.2021.6.1.0030

\begin{abstract}
Brazilian propolis AF-08 as a dietary supplement has been shown to be effective in alleviating symptoms of herpes simplex virus and respiratory syncytial virus infection in mice. The alleviation was associated with the modification of immunological activity by AF-08 as a cytokine regulator. The immunomodulatory activity of AF-08 was suggested to contribute to the severity of symptoms and pathogenesis in cytokine-mediated diseases. In this study, we investigated the effectiveness of AF-08 as a potential cytokine modulator in alleviating autoimmune diseases. The efficacy and cytokine-modulatory activity of AF-08 were examined in collagen-induced arthritis (CIA) in mice. Mice were immunized with type II collagen. AF-08 at 0,30 , or $100 \mathrm{mg} / \mathrm{kg}$ was administered orally to the immunized mice once daily for three weeks before and/or three times daily for two weeks after the onset of CIA. The development of arthritis of the paws and inflammatory cytokine levels in serum were examined. AF-08 at $100 \mathrm{mg} / \mathrm{kg}$ significantly reduced the incidence and severity of CIA prophylactically and therapeutically and reduced the rise of systemic interleukin-6 (IL-6) and tumor necrosis factor (TNF)- $\alpha$ levels in the early phase of CIA. In the early phase of CIA, the reduction of inflammatory cytokine levels by AF-08 correlated with the amelioration of symptoms of CIA. AF-08 might inhibit the initiation of cytokinemediated disease rather than suppressing disease progression without toxicity. AF-08 was confirmed to possess cytokine-modulatory activity in vivo. It is possible that AF-08 is a potential prophylactic and therapeutic agent for autoimmune diseases.
\end{abstract}

Keywords: Collagen-induced arthritis; Propolis; Cytokines; IL-6; Cytokine-modulatory activity

\section{Introduction}

Cytokine is an important factor in modulating immune responses and establishing the host defense system against microbial infection. Also, it plays primary roles directly or indirectly in the onset and development of inflammatory and autoimmune diseases and microbial infection [1-7]. The modification of cytokine production is suggested to contribute to the severity of symptoms and pathogenesis in cytokine-mediated diseases. Development of a material that modulates cytokine production in vivo could be of value in improving the management of microbial infection and autoimmune diseases.

We previously showed that traditional herbal medicines, dietary supplements, probiotics, and some components of them were effective in alleviating or exacerbating symptoms correlated with the changes of cytokine productions in

\footnotetext{
${ }^{*}$ Corresponding author: Kurokawa Masahiko

Department of Biochemistry, Graduate School of Clinical Pharmacy, Kyushu University of Health and Welfare, Nobeoka, Miyazaki 882-8508, Japan.
}

Copyright (C) 2021 Author(s) retain the copyright of this article. This article is published under the terms of the Creative Commons Attribution Liscense 4.0. 
mice [4-15]. Among them, Brazilian propolis AF-08 as a dietary supplement was shown to be effective in alleviating herpetic symptoms and augmenting immunological activity associated with IFN- $\gamma$ production-inducing Th1 immunity in mice [6]. In a model of respiratory syncytial virus (RSV) infection in mice, propolis AF-08 showed immunomodulatory activity against intranasal RSV infection [7]. The modification of immunological activity associated with cytokine production by propolis AF-08 in mice was suggested to contribute to the elucidation of various pharmacological actions of AF-08 in health and disease. Propolis AF-08 is possibly a potential cytokine modulator.

A model of collagen-induced arthritis (CIA) in mice has been shown to be useful to evaluate the importance of the inflammatory cytokines [16]. The murine model reflected inflammatory polyarthritis with similarities to rheumatoid arthritis (RA) and demonstrated that pro-inflammatory cytokines are important mediators of the pathogenic process in a model in the study of anti-cytokine therapy for RA [17] and analysis of IL-6 deficient mice [18, 19]. This murine model is also useful to evaluate the in vivo cytokine-modulatory activity of propolis AF-08 and its therapeutic efficacy. Thus, in this study, to evaluate the potential of propolis AF-08 for the treatment of autoimmune diseases, we examined its prophylactic and therapeutic and cytokine-modulatory activities in a CIA model.

\section{Material and methods}

\subsection{Propolis AF-08}

Propolis AF-08 was harvested as Myrceugenia euosma (Berg) D. Legrand in the area of Brazil that is considered its major botanical origin [6]. The voucher specimen AF0308 (propolis AF-08) was deposited at Amazonfood Co., Ltd., Tokyo, Japan, and supplied by the company. Briefly, the harvested propolis was extracted with $95 \%$ ethanol (1:1, w/w) at room temperature and dried in a drying machine under vacuum [6]. Finally, propolis AF-08 was prepared as a paste of the ethanol extract as described previously $[6,7,20]$. The propolis paste contained water at $5-7 \%$ (w/w), and about 30\% $(\mathrm{w} / \mathrm{w})$ of the original propolis was recovered. The paste was dissolved in 1\% dimethyl sulfoxide (DMSO) and administered orally to mice $[6,20]$.

\subsection{Mice}

Female DBA/1 mice (7-week-old, 15-17 g) were purchased from Charles River, Yokohama, Japan, and housed 5 per cage under a $12 \mathrm{~h}$ light $/ 12 \mathrm{~h}$ dark diurnal cycle (light at $7.00 \mathrm{a}$.m.) at $23 \pm 2{ }^{\circ} \mathrm{C}$. The mice were given normal chow (CE2, Kyudo Animal Laboratory, Kumamoto, Japan) and water ad libitum and acclimated for at least 5 days before starting an experimental procedure. The experimental protocols were approved by the Animal Experiment Committee of University of Kyushu University of Health and Welfare, Japan (23-1-07), and the animal experimentation guidelines were followed in the animal studies.

\subsection{CIA model in mice}

We examined the efficacy and cytokine-modulatory activity of propolis AF-08 in a murine CIA model, as shown in Figure 1. Freund's complete adjuvant (Difco, Detroit, MI, USA) and 2\% bovine collagen type II (Elastin Products, Owensville, MO, USA) dissolved in $0.1 \mathrm{M}$ acetic acid were equally mixed to produce an emulsion [21]. Then, the emulsion (0.2 $\mathrm{ml} /$ mouse) was intradermally injected into the buttocks of DBA/1 mice as priming. The immunized mice were intradermally boosted with the emulsion $(0.2 \mathrm{ml}) 21$ days later. Propolis AF-08 at 0,30 , or $100 \mathrm{mg} / \mathrm{kg}$ was orally administered to the primed mice (10 or 5 mice/group) once daily from day 0 to day 21 after priming and then three times daily from day 22 to 37 after priming. As a control, mock-immunized mice $(n=5)$ were administered propolis AF08 at 0 or $100 \mathrm{mg} / \mathrm{kg}$ in the same manner as the immunized mice to evaluate the toxicity of propolis AF-08. Each mouse was weighed daily after the booster. Each paw was assessed once daily for development of arthritis and scored simultaneously at least by two persons as: 0 , no swelling; 1 , swelling of one or two toes or slight swelling of an ankle; 2 , swelling of one or two toes accompanied by slight or moderate swelling of an ankle; or 3, extensive swelling of paws; the score of each mouse was expressed as the sum of scores of four paws [21].

After exsanguination at 37 days after priming, four paws of 10 mice in each group were extirpated at about $8 \mathrm{~mm}$ above the wrist and ankle joints, and the paws were weighed. The removed paws were fixed in buffered formalin and decalcified in 5\% EDTA. The paws were subsequently embedded in paraffin, sectioned, stained with hematoxylin and eosin, and analyzed histologically [21].

\subsection{Enzyme-linked immunosorbent assay (ELISA) of serum}

On days 28, 32, and 37 after priming, serum was drawn from 5 mice in each group, and the concentrations of cytokines (IL-6 and TNF- $\alpha$ ) were determined by ELISA kits (Amersham Pharmacia Biotech, Buckinghamshire, England, or 
BioSource, Camarillo, CA, USA) according to the manufacturer's instructions. Detection sensitivities of the kits were IL$6,4 \mathrm{pg} / \mathrm{ml}$ and TNF- $\alpha, 8 \mathrm{pg} / \mathrm{ml}$. The intra- and inter-assay coefficients of variation for these ELISA were less than $10 \%$.

\subsection{Statistical analyses}

Student's $t$-test was used to evaluate the significance of differences in mean cytokine levels at days examined. Fischer's exact test was used to evaluate the significance of differences in incidences of arthritic symptoms. The repeated measure two-way ANOVA (RM-ANOVA) was used to analyze the interaction between a treated group and a control in mean scores for days 28 to 37 after priming. A $p$-value of less than 0.05 was statistically defined as significant.

\section{Results}

\subsection{Efficacy of propolis AF-08 on CIA}

The efficacy of propolis AF-08 was evaluated in a CIA model using DBA/1 mice. In a preliminary experiment, the administration of propolis AF-08 at $100 \mathrm{mg} / \mathrm{kg}$ significantly reduced the incidence of CIA compared with propolis AF08 at $0 \mathrm{mg} / \mathrm{kg}(p<0.05$ by Fischer's exact test, Table 1$)$, although the reduction by AF- 08 at $30 \mathrm{mg} / \mathrm{kg}$ was not statistically significant. Also, the administration of AF-08 at $100 \mathrm{mg} / \mathrm{kg}$ was significantly effective in reducing the mean weight of forepaws ( $p<0.05$ by Student's $t$-test, Table 1), but that of AF-08 at $30 \mathrm{mg} / \mathrm{kg}$ was not. We repeated the experiment and confirmed that the development of CIA was significantly retarded by propolis AF-08 at $100 \mathrm{mg} / \mathrm{kg}$ for days 28 to 37 $(p<0.05$ RM-ANOVA for days 28 to 37, Figure 2), although propolis AF-08 at $30 \mathrm{mg} / \mathrm{kg}$ was not significantly effective. However, for days 28 to 32, both doses of propolis AF-08 at 30 and $100 \mathrm{mg} / \mathrm{kg}$ were significantly effective in suppressing the symptoms of CIA ( $p<0.05$ RM-ANOVA for days 28 to 32, Figure 2). There was no significant difference between the mean weights of mock-immunized mice administered propolis AF-08 at 0 and $100 \mathrm{mg} / \mathrm{kg}$ at 37 days (18.3 $\pm 0.3 \mathrm{~g}$ and $17.6 \pm 0.4 \mathrm{~g}$, respectively). Thus, propolis AF-08 protected mice from the onset and in the early phase of CIA and exhibited prophylactic and therapeutic efficacy against CIA in mice without toxicity.

Table 1 Effects of propolis AF-08 on collagen-induced arthritis in DBA/1 mice

\begin{tabular}{|l|l|l|l|}
\hline Compound & $\begin{array}{l}\text { Dose } \\
(\mathbf{m g} / \mathbf{k g})\end{array}$ & Incidence & $\begin{array}{l}\text { Mean weight } \\
\text { of 4 paws }\end{array}$ \\
\hline Mock-immunized mice & 0 & $0 / 5$ & $0.385 \pm 0.008$ \\
\hline Collagen-immunized mice & & & \\
\hline AF-08 & 0 & $9 / 10$ & $0.396 \pm 0.009^{\mathrm{b}}$ \\
\hline AF-08 & 30 & $5 / 10$ & $0.389 \pm 0.006$ \\
\hline AF-08 & 100 & $4 / 10^{\mathrm{a}}$ & $0.385 \pm 0.008^{\mathrm{c}}$ \\
\hline
\end{tabular}

AF- 08 at 0,30 , and $100 \mathrm{mg} / \mathrm{kg}$ was orally administered to collagen-immunized DBA1 mice after priming. Incidence of paws of 10 mice in a group were determined on day 37 after priming. The mean weights of 4 paws of 10 mice were determined on day 37 after priming. Values except in the incidence are the mean $\pm \mathrm{SE}$. a $p<0.05$ vs. AF- 08 at $0 \mathrm{mg} / \mathrm{kg}$ by Fischer's exact test. ${ }^{b} p<0.05$ vs. mock-immunized mice by Student's $t$-test. ${ }^{c} p<0.05$ vs. AF- 08 at 0 $\mathrm{mg} / \mathrm{kg}$ by Student's $t$-test.

\subsection{Histological analyses of collagen-induced arthritis}

We histologically evaluated the effect of propolis AF-08 at $100 \mathrm{mg} / \mathrm{kg}$ on CIA. No arthritic symptoms were observed for 21 days after priming in collagen-immunized mice with and without propolis AF-08, but mild inflammatory arthritis in the toes or the metatarsophalangeal joints were gradually observed from 28 days after priming (Figures 1 and 2). The immunized mice without propolis AF-08 exhibited inflammatory cell infiltration with prominent pannus formation and the joint space was filled with granulation tissue on day 37 compared with mock-immunized mice. Some severe deforming arthritis in collagen-induced mice without AF-08 was also observed at 37 days after priming (Table 2 and Figure 3, C1 and C2). On the other hand, in histological analysis of joints at 37 days after priming, propolis AF-08 noticeably alleviated inflammation of joint synovia in the collagen-immunized mice and moderately reduced the frequency of bone lysis and pannus formation (Table 2 and Figure 3, D1 and D2). In mock-immunized mice with and without propolis AF-08, arthritic symptoms were not observed at 37 days of priming (Figure 3, A and B). Thus, propolis AF-08 seemed to be histologically effective in alleviating CIA in mice. 
Table 2 Histopathological alleviation of collagen-induced arthritis by propolis AF-08

\begin{tabular}{|l|l|l|l|l|l|l|l|l|}
\hline Histopathological changes & \multicolumn{4}{l}{ Score of lesion } \\
\hline & \multicolumn{3}{|l|}{ Forepaw of mice } & \multicolumn{4}{ll}{ Hind paw of mice } \\
\hline & 1 & 2 & 3 & 4 & 1 & 2 & 3 & 4 \\
\hline Mock-immunized mice without AF-08 & & & & & & & & \\
\hline 1. Inflammation of joint synovium & - & - & - & nd & - & - & - & nd \\
\hline 2. Bone lysis & - & - & - & nd & - & - & - & nd \\
\hline 3. Formation of pannus & - & - & - & nd & - & - & - & nd \\
\hline Mock-immunized mice with AF-08 & & & & & & & & \\
\hline 1. Inflammation of joint synovium & - & - & nd & nd & - & - & nd & nd \\
\hline 2. Bone lysis & - & - & nd & nd & - & - & nd & nd \\
\hline 3. Formation of pannus & - & - & nd & nd & - & - & nd & nd \\
\hline Collagen-immunized mice without AF-08 & & & & & & & & \\
\hline 1. Inflammation of joint synovium & ++ & + & +++ & +++ & ++ & +++ & +++ & nd \\
\hline 2. Bone lysis & - & - & + & ++ & - & + & ++ & nd \\
\hline 3. Formation of pannus & - & - & - & ++ & - & - & ++ & nd \\
\hline Collagen-immunized mice with AF-08 & & & & & & & & \\
\hline 1. Inflammation of joint synovium & - & - & + & nd & + & - & - & \pm \\
\hline 2. Bone lysis & - & - & ++ & nd & - & - & - & - \\
\hline 3. Formation of pannus & - & - & +++ & nd & - & - & - & - \\
\hline
\end{tabular}

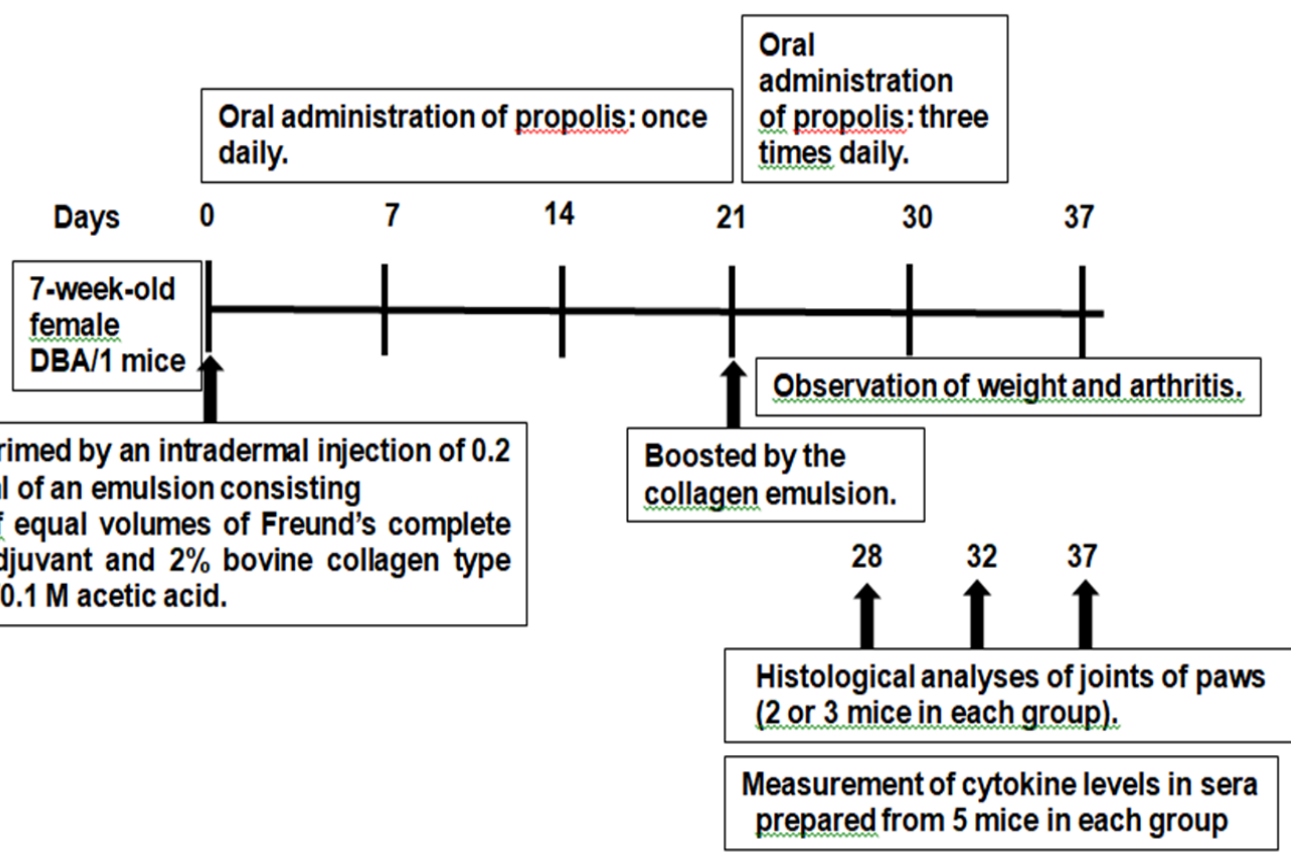

Figure 1 Experiment schedule of collagen-induced arthritis in mice. 


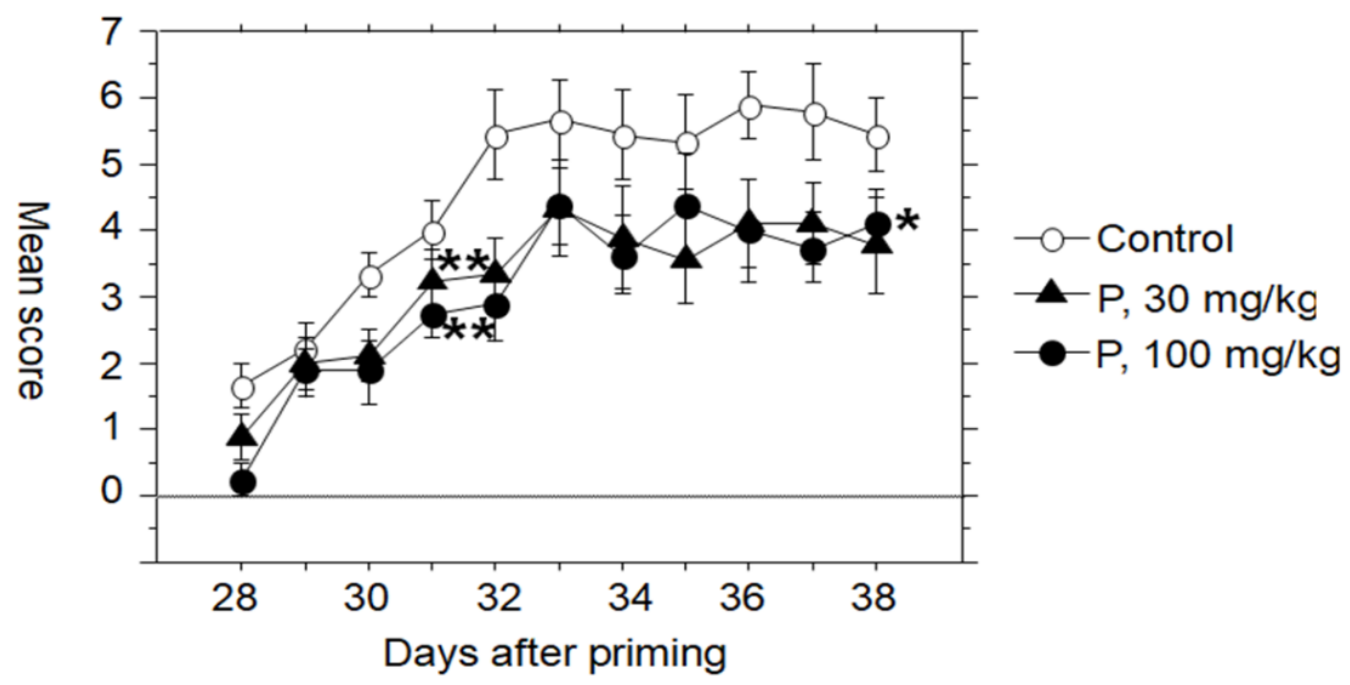

Figure 2 Prophylactic and therapeutic protection against CIA by propolis AF-08. Propolis AF-08 at 0 (O), 30 ( $\mathbf{A}$ ), or 100 $\mathrm{mg} / \mathrm{kg}(\bigcirc)$ was orally administered to immunized mice ( $\mathrm{n}=10$ per group) after priming as described in Materials and Methods. Control shows mock-immunized mice (O). Progression scores of diseases are expressed by the mean score \pm SE of mice in a group. ${ }^{*} \mathrm{p}<0.05$ vs. propolis AF- 08 at $0 \mathrm{mg} / \mathrm{kg}$ by RM-ANOVA for days 28 to 37 . ${ }^{* *}$ p $<0.05$ vs. propolis AF08 at $0 \mathrm{mg} / \mathrm{kg}$ by RM-ANOVA for days 28 to 32 .
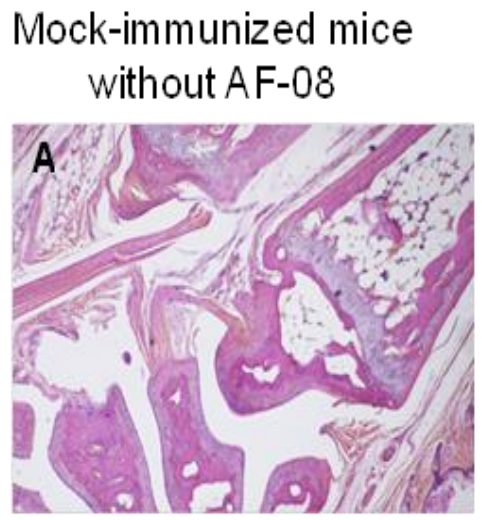

\section{Mock-immunized mice with AF-08}

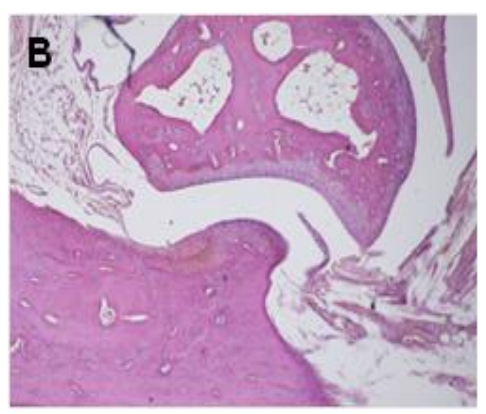

Collagen-immunized without AF-08
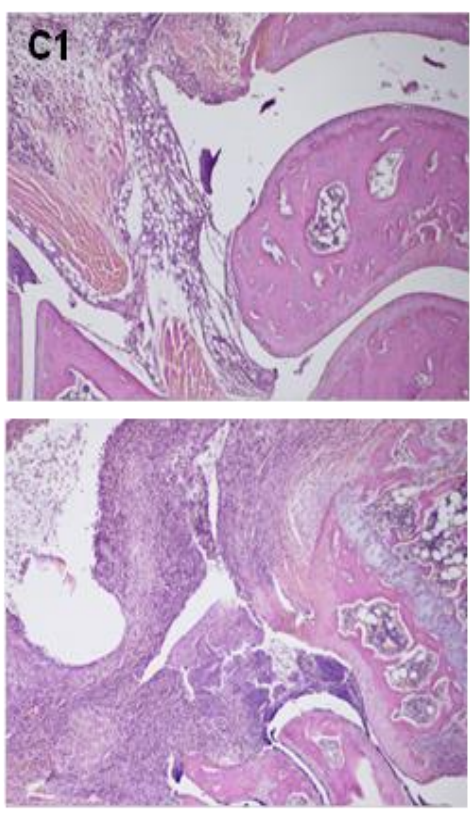

\section{Collagen-immunized} with AF-08
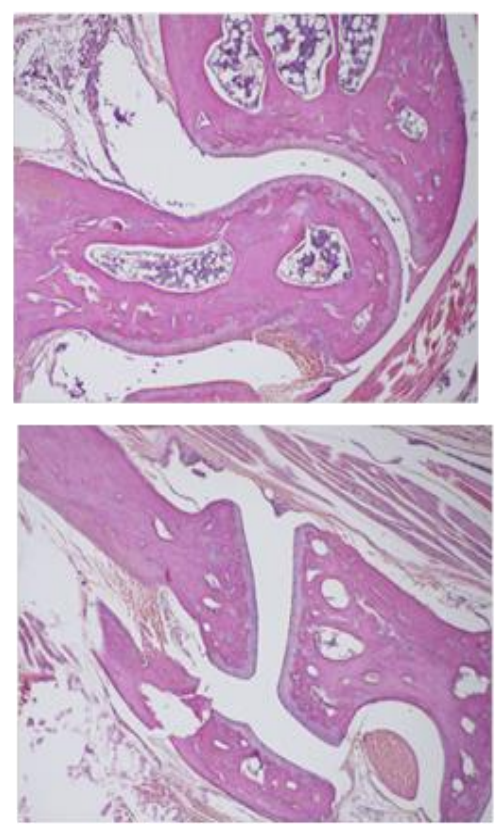

Figure 3 Effect of propolis AF-08 administration on histological features of joints from collagen-immunized mice. A, mock-immunized mice without propolis AF-08 at $100 \mathrm{mg} / \mathrm{kg}$. B, mock-immunized mice with propolis AF-08 at 100 $\mathrm{mg} / \mathrm{kg}$. C1 and C2, immunized mice without propolis AF-08 at $100 \mathrm{mg} / \mathrm{kg}$. D1 and D2, immunized mice with propolis $\mathrm{AF}-08$ at $100 \mathrm{mg} / \mathrm{kg}$. 


\subsection{Effect of propolis AF-08 on pro-inflammatory cytokine production in CIA}

Pro-inflammatory cytokine (TNF- $\alpha$ and IL-6) levels in the sera of immunized mice treated with and without propolis AF-08 at $100 \mathrm{mg} / \mathrm{kg}$ in the CIA model were compared (Tables 3 and 4). In mock-immunized mice, propolis AF-08 at $100 \mathrm{mg} / \mathrm{kg}$ did not affect the basal levels of TNF- $\alpha$ on days 28 and 37 (Table 3). In immunized mice treated without propolis AF-08 at $100 \mathrm{mg} / \mathrm{kg}$, the TNF- $\alpha$ level increased from day 28 to day 32 and the increased level decreased on day 37 (Table 3). However, TNF- $\alpha$ levels in the mice treated with propolis AF-08 at $100 \mathrm{mg} / \mathrm{kg}$ were lower than that in the mice treated without propolis AF-08 on day 28, although it was not statistically significant. On days 32 and 37 , reduction of the TNF- $\alpha$ level was not observed in mice treated with propolis AF-08 at $100 \mathrm{mg} / \mathrm{kg}$. Propolis AF-08 seemed to be effective in reducing the TNF- $\alpha$ level in the early phase of CIA.

Table 3 Effects of propolis AF-08 on TNF- $\alpha$ levels of sera in collagen-immunized DBA/1 mice . $^{2}$

\begin{tabular}{|l|l|l|l|}
\hline \multirow{2}{*}{ Treatment } & \multicolumn{3}{|l|}{ TNF- $\alpha$ levels $(\mathbf{p g} / \mathbf{m l})$ after priming } \\
\cline { 2 - 4 } & 28 days & 32 days & 37 days \\
\hline Mock-immunized mice & & & \\
Control & $20.5 \pm 5.0$ & $30.2 \pm 21.0$ & $<8.0$ \\
Propolis AF-08 (100 mg/kg) & $28.7 \pm 23.5$ & - & $<8.0$ \\
\hline Immunized mice & & & \\
Control & $192.2 \pm 31.0$ & $214.0 \pm 37.9$ & $141.6 \pm 17.1$ \\
Propolis AF-08 (100 mg/kg) & $141.7 \pm 25.9$ & $221.7 \pm 71.2$ & $200.6 \pm 99.4$ \\
\hline
\end{tabular}

TNF- $\alpha$ levels in the sera prepared from mock-immunized or immunized mice (5 mice in each group) on days 28, 32, and 37 after priming. Values indicate mean \pm SE for 5 mice in each group.

In mock-immunized mice, propolis AF-08 at $100 \mathrm{mg} / \mathrm{kg}$ did not affect the basal levels of IL-6 on days 28 and 37 (Table 4). IL-6 levels were significantly reduced by propolis AF-08 at $100 \mathrm{mg} / \mathrm{kg}$ on days 28 and 32 (Table 4). However, on day 37, propolis AF-08 at $100 \mathrm{mg} / \mathrm{kg}$ did not affect the IL-6 level in immunized mice without propolis AF-08 at 100 $\mathrm{mg} / \mathrm{kg}$. Propolis AF-08 at $100 \mathrm{mg} / \mathrm{kg}$ was effective in reducing IL-6 level in the early phase of CIA.

Table 4 Effects of propolis AF-08 on IL-6 levels of sera in collagen-immunized DBA/1 mice

\begin{tabular}{|l|l|l|l|}
\hline \multirow{2}{*}{ Treatment } & \multicolumn{3}{|l|}{ IL-6 levels (pg/ml) after priming } \\
\cline { 2 - 4 } & 28 days & 32 days & 37 days \\
\hline Mock-immunized mice & & & \\
Control & $40.2 \pm 11.0$ & $11.0 \pm 14.6$ & $<4.0$ \\
AF-08 (100 mg/kg) & $11.7 \pm 10.1$ & - & $30.1 \pm 42.6$ \\
\hline Immunized mice & & & \\
Control & $137.9 \pm 34.3$ & $209.4 \pm 20.8$ & $114.2 \pm 33.4$ \\
AF-08 $(100 \mathrm{mg} / \mathrm{kg})$ & $43.9 \pm 5.1^{\mathrm{a}}$ & $94.5 \pm 14.6^{\mathrm{b}}$ & $156.5 \pm 15.0$ \\
\hline
\end{tabular}

IL-6 levels in the sera prepared from mock-immunized or immunized mice (5 mice in each group) on days 28, 32 , and 37 after priming Values indicate mean \pm SE for 5 mice in each group. a $p<0.05$ vs. control by Student's $t$-test. b $p<0.01$ vs. control by Student's $t$-test.

\section{Discussion}

We evaluated the prophylactic and therapeutic efficacy and cytokine-modulatory activity of propolis AF-08 in a CIA model. Propolis AF-08 was effective in alleviating the symptoms of CIA and suppressing the rise of systemic levels of inducible TNF- $\alpha$ and IL-6. The suppression of TNF- $\alpha$ and IL- 6 levels correlated with the alleviation of symptoms in the early phase of CIA. Thus, propolis AF-08 may be a potential prophylactic and therapeutic supplement for autoimmune diseases such as RA.

Prophylactic and therapeutic oral administration of propolis AF-08 at $100 \mathrm{mg} / \mathrm{kg}$ alleviated CIA in DBA/1 mice till day 37 after priming (Table 1 and Figure 2). No significant weight changes of mock-immunized mice were observed due to the oral administration of propolis AF-08 at $100 \mathrm{mg} / \mathrm{kg}$ compared with control, indicating that propolis AF-08 is not 
toxic. Propolis AF-08 at $100 \mathrm{mg} / \mathrm{kg}$ exhibited noticeable suppressive action on the hitopathological features of joints on day 37 after priming (Table 2 and Figure 3). Finally, propolis AF-08 reduced the incidence of arthritis, and the efficacy of propolis AF-08 was associated with the protection of joints against severe damage (Table 2 and Figure 3). When $30 \mathrm{mg} / \mathrm{kg}$ of propolis AF-08 as well as its $100 \mathrm{mg} / \mathrm{kg}$ was orally administered, the development of arthritic symptoms on days 28 to 32 was significantly suppressed (Figure 2). In the development of arthritis in collagenimmunized mice, mild inflammatory of joints arthritis, manifested as the swelling of the paws, developed initially and then severe deforming arthritis was observed [21]. Thus, propolis AF-08 prophylactically appeared to be effective in suppressing the onset of arthritis. The significant reduction in the incidence of arthritis and the significant protection against severe damage might result from suppression of the initial development of arthritis. Therefore, the efficacy of propolis AF-08 given prophylactically and therapeutically may render it a candidate for the treatment of autoimmune diseases such as RA.

Cytokines, especially pro-inflammatory cytokines, play a pivotal role in the pathology of RA [22]. Their biological actions appear to contribute to acute and chronic inflammation, cell proliferation, and tissue destruction/fibrosis in the pathology of RA. IL-6 plays a key role in the development of arthritis $[18,19]$. A high level of IL- 6 was observed in both the serum and synovial fluids of RA patients [22] and was suggested to be useful marker for RA activity [23]. In this study, propolis AF-08 at $100 \mathrm{mg} / \mathrm{kg}$ significantly suppressed the rise of IL-6 level in serum in the early phase of CIA (Table 4), and the suppression correlated with the reduction of the severity of arthritis (Figure 2). In our murine CIA model, the systemic IL-6 levels were higher at the early phase of CIA than at the phase of severe arthritis, and these high levels were significantly suppressed by propolis AF-08 (Table 4). Thus the efficacy of propolis AF-08 was related to the systemic suppression of the IL-6 level in mice. Propylactic propolis AF-08 was suggested to inhibit the onset of CIA, possibly by suppressing the elevated IL-6 level at the initiation of arthritis.

The disease-promoting role of TNF- $\alpha$ in RA has been well established [24], and agents that reduce levels of systemic TNF- $\alpha$ are in clinical use [25]. TNF- $\alpha$ is easily detectable in synovial fluid [26, 27], and many investigators have demonstrated worsening of CIA following treatment with TNF- $\alpha[28,29]$. In our CIA model (Table 3), propolis AF-08 moderately reduced the systemic TNF- $\alpha$ level on day 28 corresponding to the initiation of arthritis, but did not affect the systemic TNF- $\alpha$ levels on days 32 and 37 corresponding to the development of severe arthritis. Propolis AF-08 might not initially contribute to the suppression of severity of CIA through the reduction of systemic TNF- $\alpha$ levels.

Propolis AF-08 reduced systemic levels of IL-6 and TNF- $\alpha$ in the CIA model (Tables 3 and 4). Previously, propolis AF08 was shown to inhibit transcription of IL-1 $\alpha$, TNF- $\alpha$, and IL- 6 in lipopolysaccharide-treated murine macrophage-like P388D1 cells [15]. In a murine endotoxin shock model, propolis AF-08 suppressed the rise of IL-6 and TNF- $\alpha$ levels in serum [15]. However, propolis AF-08 administration did not affect the basal levels of IL-1 $\alpha$, TNF- $\alpha$, and IL-6 in normal mice [15]. Thus, the differences may be due to the inducing stimuli, the target cells, and their sensitivity in responding to propolis AF-08. Propolis AF-08 may have a novel ability to modulate specific cytokine levels only in response to specific stimuli without affecting the basal levels in vivo.

\section{Conclusion}

In this study, we demonstrated that propolis AF-08 exhibited prophylactic and therapeutic efficacy against CIA. The results presented here suggest that the cytokine-suppressive activity of propolis AF-08 is associated with its efficacy. Propolis AF-08 reduced the rise of systemic levels of IL- 6 to their basal levels in the serum of normal mice. Propolis AF08 is a cytokine-modulator specific for inducible cytokines, especially pro-inflammatory cytokines, in cytokinemediated diseases, and would be a potential prophylactic and therapeutic agent for cytokine-mediated diseases.

\section{Compliance with ethical standards}

\section{Acknowledgments}

We thank Ms. T. Shimosa for her excellent technical assistance. We also thank Ms. Katherine Ono for her editorial assistance.

\section{Disclosure of conflict of interest}

The authors declare that there is no conflict of interest in manuscript submitted. 
The experimental protocols were approved by the Animal Experiment Committee of University of Kyushu University of Health and Welfare, Japan (23-1-07), and the animal experimentation guidelines of the university were followed in the animal studies.

\section{References}

[1] Yao X, Huang J, Zhong H, Shen N, Faggioni R, Fung M, Yao Y. Targeting interleukin-6 in inflammatory autoimmune diseases and cancers. Pharmacology and Therapeutics. 2014; 141(2): 125-139.

[2] Blanco P, Palucka AK, Pascual V, Banchereau J. Dendritic cells and cytokines in human inflammatory and autoimmune diseases. Cytokine Growth Factor Reviews. 2008; 19(1): 41-52.

[3] Tsurita M, Kurokawa M, Imakita M, Fukuda Y, Watanabe Y, Shiraki K. Early augmentation of interleukin (IL)-12 level in the airway of mice administered orally with clarithromycin or intranasally with IL-12 results in alleviation of influenza infection. Journal of Pharmacology and Experimental Therapeutics. 2001; 298(1): 362368.

[4] Kurokawa M, Tsurita M, Brown J, Fukuda Y, Shiraki K. Effect of interleukin-12 level augmented by Kakkon-to, an herbal medicine, on the early stage of influenza infection in mice. Antiviral Research. 2002; 56(2): $183-188$.

[5] Kurokawa M, Watanabe W, Shimizu T, Sawamura R, Shiraki K. Modulation of cytokine production by 7hydroxycoumarin in vitro and its efficacy against influenza infection in mice. Antiviral Research. 2010; 85(2): 373-380.

[6] Shimizu T, Takeshita Y, Takamori Y. et al. Efficacy of Brazilian propolis against herpes simplex virus type 1 infection in mice and their modes of anti-herpetic efficacies. Evidence-Based Complementary and Alternative Medicine. 2011; Article ID 976196, 9.

[7] Takeshita T, Watanabe W, Toyama S. et al. Effect of Brazilian propolis on exacerbation of respiratory syncytial virus infection in mice exposed to tetrabromobisphenol A, a brominated flame retardant. Evidence-Based Complementary and Alternative Medicine. 2013; Article ID 6982062013.

[8] Matsusaki T, Takeda S, Takeshita M. et al. Augmentation of T helper type 1 immune response through intestinal immunity in murine cutaneous herpes simplex virus type 1 infection by probiotic Lactobacillus plantarum strain 06CC2. International Immunopharmacology. 2016; 39: 320-327.

[9] Takeda S, Hidaka M, Yoshida H. et al. Anti-allergic activity of probiotics from Mongolian dairy products on type I allergy in mice and mode of anti-allergic action. Journal of Functional Foods. 2014; 9(1): 60-69.

[10] Hagiwara A, Hidaka M, Takeda S. et al. Anti-allergic action of aqueous extract of Moringa oleifera Lam. leaves in mice. European Journal of Medicinal Plants. 2016; 16(3): 1-10.

[11] Kurokawa M, Imakita M, Kumeda CA, Shiraki K. Cascade of fever production in mice infected with influenza virus. Journal of Medical Virology. 1996; 50(2): 152-158.

[12] Kurokawa M, Imakita M, Kumeda CA, Yukawa TA, Shiraki K. Kakkon-to suppressed interleukin-1 $\alpha$ production responsive to interferon and alleviated influenza infection in mice. Journal of Traditional Medicines. 1996; 13: 201-209.

[13] Kurokawa M, Kumeda CA, Yamamura J, Kamiyama T, Shiraki K. Antipyretic activity of cinnamyl and related compounds in Kakkon-to, a traditional medicine, in influenza virus-infected mice. European Journal of Pharmacology. 1998; 348(1): 45-51.

[14] Kurokawa M, Tsurita M, Brown J, Fukuda Y, Shiraki K. Effect of interleukin-12 level augmented by Kakkon-to, an herbal medicine, on the early stage of influenza infection in mice. Antiviral Research. 2002; 56(2): $183-188$.

[15] Kurokawa M, Brown J, Kagawa Y, Shiraki K. Cytokine-regulatory activity and therapeutic efficacy of cynnamyl derivatives in endotoxin shock. European Journal of Pharmacology. 2003; 474 (2-3): 283-293.

[16] Williams RO, Mason LJ, Feldmann M, Maini RN. Synergy between anti-CD4 and anti-TNF in the amelioration of established collagen-induced arthritis. Proceedings of the National Academy of Sciences of the United States of America. 1994; 91(7): 2762-2766.

[17] Moreland LW, Baumgartne SW, Schiff MH. et al. Treatment of rheumatoid arthritis with a recombinant human tumor necrosis factor receptor (p75)-Fc fusion protein. New England Journal of Medicine. 1997; 337(3): 141147. 
[18] Alonzi T, Fattori E, Lazzaro D. et al. Interleukin 6 is required for the development of collagen-induced arthritis. Journal of Experimental Medicine. 1998; 187(4): 461-468.

[19] Ohshima S, Saeki Y, Mima T. et al. Interleukin-6 plays a key role in the development of antigen-induced arthritis. Proceedings of the National Academy of Sciences of the United States of America. 1998; 95(14): 8222-8226.

[20] Shimizu T, Hino A, Tsutsumi A, Park YK, Watanabe W, Kurokawa M. Anti-influenza virus activity of propolis in vitro and its efficacy against influenza infection in mice. Antiviral Chemistry \& Chemotherapy. 2008; 19(1): 7-14.

[21] Kurokawa M, Imakita M, Shiraki K. Cytokine-modulatory activity and therapeutic efficacy of 7-amino-4methylcoumarin in murine collagen-induced arthritis. Open Bioactive Compounds Journal. 2010; 3: 12-17.

[22] Feldmann M, Brennan FM, Maini RN. Role of cytokines in rheumatoid arthritis. Annual Review of Immunology. 1996; 14: 397-440.

[23] Houssiau FA, Devogelaer JP, Van Damme J, de Deuxchaines CN, Van Snick J. Interleukin-6 in synovial fluid and serum of patients with rheumatoid arthritis and other inflammatory arthritides. Arthritis \& Rheumatology. 1998; 31(6): 784-788.

[24] Feldmann M, Maini RN. Anti-TNF alpha therapy of rheumatoid arthritis: what have we learned? Annual Review of Immunology. 2001; 19(1): 163-196.

[25] Macias I, Garcia-Perez S, Ruiz-Tudela M, Medina F, Chozas N, Giron-Gonzalez JA. Modification of pro- and antiinflammatory cytokines and vascular-related molecules by tumor necrosis factor- $\alpha$ blockade in patients with rheumatoid arthritis. Journal of Rheumatology. 2005; 32(11): 2102-2108.

[26] Di Giovine FS, Nuki G, Duff GW. Tumour necrosis factor in synovial exudates. Annals of the Rheumatic Diseases. 1988; 47(9): 768-772.

[27] Saxne T, Palladino MA, Jr. Heinegard D, Talal N, Wollheim FA. Detection of tumor necrosis factor alpha but not tumor necrosis factor beta in rheumatoid arthritis synovial fluid and serum. Arthritis and Rheumatology. 1988; 31(8): 1041-1045.

[28] Cooper WO, Fava RA, Gates CA, Crèmer MA, Townes AS. Acceleration of onset of collagen-induced arthritis by intra-articular injection of tumour necrosis factor or transforming growth factor-beta. Clinical \& Experimental Immunology. 1992; 89(2): 244-250.

[29] Brahn E, Peacock DJ, Banquerigo ML, Liu DY. Effects of tumor necrosis factor alpha (TNF-alpha) on collagen arthritis. Lymphokine and Cytokine Research. 1992; 11(5): 253-256. 